\title{
Correction to: From the Editor
}

\author{
Charles Steindel $^{1}$
}

Published online: 5 July 2021

(c) National Association for Business Economics 2021

\section{Correction to: Business Economics}

https://doi.org/10.1057/s11369-021-00231-6

An earlier version discussed a speech by Dr. Klaus Knot, of De Nederlandsche Bank and the Financial Stability Board. The reference to this speech has been removed. For those interested, the speech is available at https:// www.fsb.org/2021/05/rebuilding-resilience-the-finan cial-system-after-the-covid-crisis/.

Publisher's Note Springer Nature remains neutral with regard to jurisdictional claims in published maps and institutional affiliations.

The original article can be found online at https://doi.org/10.1057/ s11369-021-00231-6.

Charles Steindel

csteindel@nabe.com

1 NABE, Washington, USA 